\title{
SOME ASPECTS OF OSMOREGULATION IN EMBRYONIC AND ADULT CYMATOGASTER AGGREGATA AND OTHER EMBIOTOCID FISHES
}

\author{
EDWARD L. TRIPLETT AND SUSANNE D. BARRYMORE \\ Department of Biological Sciences, University of California, Santa Barbara, \\ Goleta, California
}

The Embiotocidae is a family of marine (with one exception) teleosts which is somewhat unique in that all species possess a truly viviparous type of development. The young remain in the hollow ovary of the parent for a period of about five months, during which time they increase in size from $0.24 \mathrm{~mm}$. (fertilized egg) to about $42 \mathrm{~mm}$. (newborn) (Eigenmann, 1890, 1894). It was learned while devising a technique for culturing the embryos in vitro (Triplett, unpublished) that, unlike the adults, they are capable of tolerating only very limited variation in the osmotic concentration of the external medium.

The object of this study was to learn more precisely how well these animals can regulate to variations in the concentration of the external medium both as adults and during development. In addition, preliminary experiments were performed in an effort to find out why the adults are better able to regulate than the embryos.

\section{Materials And Methods}

\section{Experimental animals}

Cymatogaster aggregata (Gibbons) was the most easily obtained of the embiotocids and was therefore the principal organism used in the investigation. This species is widely distributed over the west coast of North America, ranging from southern Alaska through Baja California (Tarp, 1952). It has been observed in estuaries where the salinity is quite variable (Hubbs, 1917) as well as in bays and along the open coast. Animals used in these experiments were collected by angling from Goleta Pier, Goleta, California.

Less extensively investigated were Amphistichus argenteus (Agassiz) and Micrometrus minimus (Gibbons). These species have about the same distribution as $C$. aggregata, but so far as the authors are aware, they do not enter brackish water. For these experiments they were collected with a beach seine on the campus beach at Goleta, California. Only adults of these two species were used.

\section{Methods}

The general approach was to determine the total osmotic pressure of the serum and the change in body weight after exposure to experimental salinities for periods ranging from six hours to nine days.

1 These studies were aided by a contract between the Office of Naval Research, Department of the Navy, and the Regents of the University of California, NR 104-466, and by a Grant from the Research Committee of the University of California, Santa Barbara, Goleta, California. 
The experimental animals were divided into four groups on the basis of their stages of development. Group 1 comprised intra-ovarian embryos ranging in standard length from $18 \mathrm{~mm}$. to $25 \mathrm{~mm}$. At this stage the animals were completely transparent except for a thin band of melanophores along the lateral line and a few scattered melanophores in the head region. The fins were hypertrophied and possessed highly vascularized dermal flaps between the rays. The hindgut was also hypertrophied and protruded in the cloacal area. The fins and hindgut probably serve as a pseudo-placenta (Eigenmann, 1890, 1894). The trailing edge of the caudal fin was convex or flat. Group 2 consisted of intra-ovarian embryos measuring between $27 \mathrm{~mm}$. and $31 \mathrm{~mm}$. in standard length. These animals still possessed hypertrophied fins and a hypertrophied protruding hindgut. Melanin deposition had increased considerably, and guanophores appeared on the dorsal half of the animal, rendering it semi-opaque. Scales had differentiated visibly at this time. The trailing edge of the caudal fin was becoming concave. Group 3 comprised intra-ovarian animals nearing parturition age and ranging in standard length from $32 \mathrm{~mm}$. to $38 \mathrm{~mm}$. The body was completely opaque and the adult pigment pattern was acquired. The fins, though not yet of adult proportion, had begun to atrophy. The hindgut had also atrophied and protruded only slightly. The trailing edge of the caudal fin was deeply concave and V-shaped as in the adult. Group 4 comprised newborn animals and adults measuring between $39 \mathrm{~mm}$. and $115 \mathrm{~mm}$. standard length. Preliminary experiments on group 4 animals of different lengths (ages) established that their osmotic responses were identical.

A minimum of four animals from each group was placed directly from holding tanks (running sea water) or directly from the ovarian cavity into each of the following solutions of sea water diluted with distilled water: $100 \%(\triangle=1.86)$, $75 \%, 50 \%, 25 \%, 20 \%, 15 \%$. For each series of measurements four adult animals were kept in an aerated battery jar containing $3000 \mathrm{ml}$. of fluid and maintained at $16^{\circ} \mathrm{C}$., or four embryos were kept aseptically in a fingerbowl containing $1000 \mathrm{ml}$. of fluid and maintained at the same temperature. Serum freezing point determinanations and weight measurements were made on four different animals of each group at each dilution after six hours and one, two, four and eight or nine days. Freezing points are here given in sodium chloride equivalents.

Weight determinations were made on blotted animals with a triple beam balance to an accuracy of 0.01 gram. All animals in group 4 were weighed before and after exposure to the experimental medium. Weight measurements were not possible with groups 1,2 , and 3 because these animals will not live after such handling.

Blood for freezing point determinations was taken by cardiac puncture or by removal of the tail at the level of the caudal peduncle. In the adults the particulate matter was removed before placing the serum in capillaries. This was not possible with the embryos since too little blood was available. Instead the freezing point capillary was inserted into the heart, and whole blood was drawn into the tube. The red cells and the clot were then packed by centrifuging, thus rendering the serum clear enough for freezing point determinations. Freezing points were determined with an apparatus modified after one used by Gross (1954), and since the modification offers some advantages over the original it is briefly described here. It consists of a Fiberglas-lined, insulated box containing four meters of onehalf inch copper tubing. Two glass windows allow light to be passed through 
the box. The box is filled with brine, and the brine is cooled by circulating freon14 through the copper tubing. When the desired temperature is obtained the freon-14 is turned off, and the previously frozen capillaries containing the fluid to be measured are inserted in the brine between the observation windows. As the box warms very slowly the fluid in the capillaries melts. The melting point can be observed with great accuracy $\left( \pm 0.02^{\circ} \mathrm{C}\right.$.) by using crossed polaroids.

In an effort to learn something about differences in ionic exchange between different age groups preliminary experiments have been performed using chlorine36 as a tracer. The technique consisted of placing the experimental animal, after peritoneal injection of radio-chloride, in a divided chamber so that the gills and half the body were on one side. Aliquots of the fluid in the two compartments were measured at intervals over a three- to eleven-hour period for radioactivity. The fluid in both compartments was a modified White's (1954) medium (.220 $M / \mathrm{L} \mathrm{NaCl}$ equiv.) slightly hypertonic to the serum.

\section{Results AND Discussion}

\section{Changes in serum freezing point and body weight in experimental media}

Cymatogaster aggregata: The results of freezing point determinations and weight measurements on adult (group 4) $C$. aggregata are summarized in Figure 1 , each point on the graph representing the average of measurements made of at least four fishes. It can be seen that the viable range of salinities for this species is quite large, ranging in these experiments from 20 per cent to 100 per cent sea water. Adults remained alive no longer than three hours in 15 per cent sea water, during which time they increased 3.83 per cent in weight.

At all salinities below 100 per cent sea water there was an initial drop in serum tonicity which reached a minimal value between one and two days after exposure to the experimental media. Accompanying this was a corresponding increase in wet weight. In general, the minimal serum osmotic value decreased as the salinity of the external medium was decreased. Less convincingly, Figure 1 indicates that as the salinity of the external medium is decreased, the time required for return to normal weight and serum tonicity increases. At all salinities tested above 20 per cent sea water, regulation is complete or nearly complete within nine days.

It will be noted that there was a small temporary increase in serum tonicity and decrease in wet weight of fishes maintained in 100 per cent sea water. The authors attribute this to an increased permeability of the integument resulting from handling. It is presumed that a similar increase in integumentary permeability was also experienced by fishes kept in other sea water dilutions, and this must be kept in mind when interpreting the results.

The results of freezing point determinations on the various embryonic stages are summarized in Table I, and corresponding figures for the adults are included for comparison. It can be seen that the viable range of salinities for embryos increases with increase in age. Group 1 and group 2 were able to survive for the complete duration of the experiment only in media between 25 and 36 per cent sea water ( 36 per cent sea water is equivalent osmotically to the ovarian fluid in which the animals normally reside), whereas group 3 was capable of regulation at all salinities between 25 and 75 per cent sea water.

However, it was noted that, in general, it required a greater alteration of the 
serum osmotic potential of embryos than of adults to kill the animals. In these experiments group 1 and group 2 animals died when this value was above $.232 \mathrm{M} / \mathrm{L}$ or below .114 M/L. Group 3 animals died at values above $.223 \mathrm{M} / \mathrm{L}$ or below $.156 \mathrm{M} / \mathrm{L}$. Possibly for this reason the embryos live longer at 15 per cent sea water than do the adults. This may be a reflection of the fact that less differentiated systems are generally more tolerant of their physiological environment.
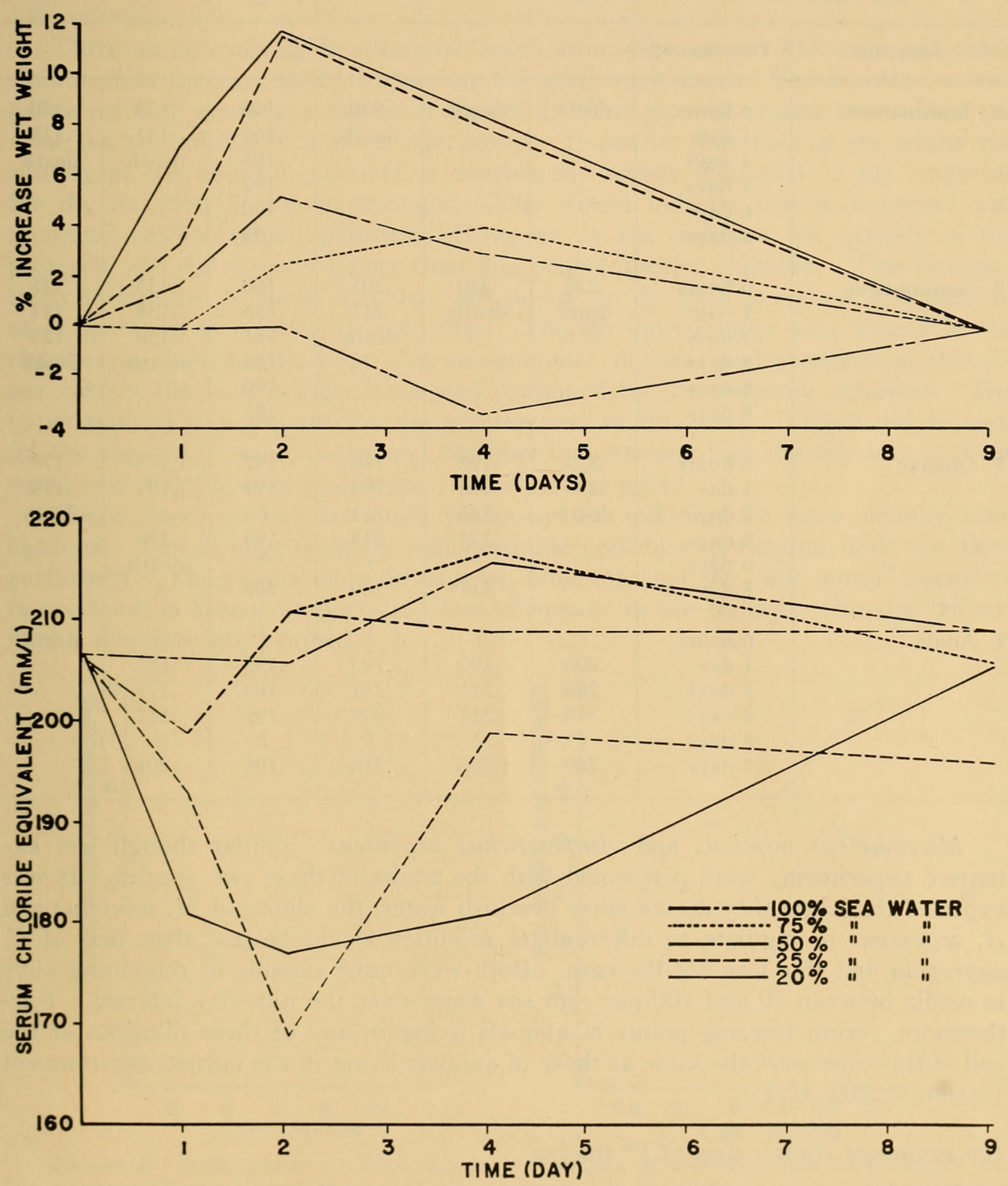

FigURE 1. Upper graph: the wet weight of $C$. aggregata adults plotted as a function of time media of different salinities. Lower graph: tonicity (sodium chloride equivalents) of C. aggregata adult serum plotted as a function of time in media of different salinities. 
TABLE I

Serum tonicity of C. aggregata of different developmental stages after exposure to media of variable salt concentrations for variable intervals of time

\begin{tabular}{|c|c|c|c|c|c|c|c|}
\hline \multicolumn{8}{|c|}{ External medium } \\
\hline \multicolumn{2}{|c|}{$\begin{array}{l}\% \text { Sea water } \\
\text { NaCl equiv. }(M / \mathrm{L})\end{array}$} & $\begin{array}{l}100 \\
.568\end{array}$ & $\begin{array}{l}75 \\
.326\end{array}$ & $\begin{array}{l}50 \\
.284\end{array}$ & $\begin{array}{l}25 \\
.142\end{array}$ & $\begin{array}{l}20 \\
.114\end{array}$ & $\begin{array}{l}15 \\
.085\end{array}$ \\
\hline Age group & Time exposed & & & & & & \\
\hline 1. Transparent & $\begin{array}{l}6 \text { hours } \\
1 \text { day } \\
2 \text { days } \\
4 \text { days } \\
6 \text { days } \\
8 \text { days }\end{array}$ & death & death & $\begin{array}{c}.230 \\
\text { death }\end{array}$ & $\begin{array}{l}.160 \\
.164 \\
.185 \\
.192 \\
.190 \\
.195\end{array}$ & $\begin{array}{c}.135 \\
.131 \\
\text { death }\end{array}$ & $\begin{array}{r}.120 \\
.115 \\
\text { death }\end{array}$ \\
\hline 2. Semi-opaque & $\begin{array}{l}6 \text { hours } \\
1 \text { day } \\
2 \text { days } \\
4 \text { days } \\
6 \text { days } \\
8 \text { days }\end{array}$ & $\begin{array}{c}.232 \\
\text { death }\end{array}$ & $\begin{array}{c}.210 \\
\text { death }\end{array}$ & $\begin{array}{c}.205 \\
.245 \\
\text { death }\end{array}$ & $\begin{array}{l}.160 \\
.156 \\
.181 \\
.185 \\
.190 \\
.195\end{array}$ & $\begin{array}{r}.135 \\
.138 \\
.158 \\
\text { death }\end{array}$ & $\begin{array}{r}.125 \\
.114 \\
.125 \\
\text { death }\end{array}$ \\
\hline 3. Opaque & $\begin{array}{l}6 \text { hours } \\
1 \text { day } \\
2 \text { days } \\
4 \text { days } \\
6 \text { days } \\
8 \text { days }\end{array}$ & $\begin{array}{c}.227 \\
.233 \\
\text { death }\end{array}$ & $\begin{array}{c}.198 \\
.202 \\
.236 \\
.221 \\
? \\
.211\end{array}$ & $\begin{array}{c}.196 \\
.209 \\
.221 \\
.215 \\
? \\
.209\end{array}$ & $\begin{array}{c}.192 \\
.191 \\
? \\
.195 \\
? \\
.206\end{array}$ & $\begin{array}{c}.198 \\
.197 \\
? \\
.156 \\
\text { death }\end{array}$ & $\begin{array}{r}.179 \\
.179 \\
\text { death }\end{array}$ \\
\hline 4. Adult & $\begin{array}{l}6 \text { hours } \\
1 \text { day } \\
2 \text { days } \\
4 \text { days } \\
6 \text { days } \\
9 \text { days }\end{array}$ & $\begin{array}{c}? \\
.206 \\
.206 \\
.216 \\
? \\
.209\end{array}$ & $\begin{array}{c}? \\
.199 \\
.211 \\
.217 \\
? \\
.206\end{array}$ & $\begin{array}{c}? \\
.193 \\
.211 \\
.209 \\
? \\
.216\end{array}$ & $\begin{array}{c}? \\
.193 \\
.169 \\
.199 \\
? \\
.196\end{array}$ & $\begin{array}{c}? \\
.181 \\
.177 \\
.181 \\
? \\
.209\end{array}$ & death \\
\hline
\end{tabular}

Micrometrus minimus and Amphistichus argenteus: Similar though less extensive experiments were performed with the adults of these two species. It was expected that since they do not enter brackish water, the ability of $M$. minimus and $A$. argenteus to regulate to differentiate salinities would be less than that of $C$. aggregata, but this was not the case. Both were quite capable of remaining alive in media between 20 and 100 per cent sea water over the nine-day interval. Furthermore, serum freezing points of animals living in any of these dilutions at the end of this time were the same as those of animals living in the normal environment $($ serum $=.209 \mathrm{M} / \mathrm{L})$.

\section{Ion exchange studies using $\mathrm{Cl}^{36}$ tracers}

The decreased ability of embryos to regulate to different tonicities of the external medium as compared to adults could be explained in several ways. One possible explanation is that these animals may not yet have differentiated the 
branchial salt secretory mechanism that has been demonstrated in various adult teleost fishes (Smith, 1930). Both adults and embryos of C. aggregata were examined for this mechanism by utilizing the divided box technique first used by Smith (1930). The animals were injected intraperitoneally with $0.25 \mathrm{ml}$. of an isotonic salt solution with an activity of 0.125 microcuries per milliliter. At twohour intervals or less, 250-lambda samples were withdrawn from the anterior and from the posterior chambers and measured for radioactivity with an accuracy of 1.0 per cent.

Three adults ranging in standard length from $105 \mathrm{~mm}$. to $115 \mathrm{~mm}$. and three sibling embryos (group 3) measuring $33 \mathrm{~mm}$. were used. The results for one animal of each group are shown in Figure 2. The general results were about the same for any animal in a given age group. It can be seen that in the adults the activity of the anterior chamber is consistently higher than that of the posterior for the duration of the experiment. This would indicate that a branchial salt secretory mechanism is operative. However, in the embryos, the activity of the posterior was consistently higher than that of the anterior chamber. This is tentatively interpreted to mean that the "salt pump" in the gills is not yet in operation or is operating at a much reduced rate. Though the embryos were placed in the chamber so that half the body was on each side, it was roughly estimated that 74 per cent of the body surface area was contained by the posterior chamber. The hypertrophied fins account for the greater part of this area. This could account for the higher $\mathrm{Cl}^{36}$ value in the rear chamber by assuming that chloride loss is about equal over the whole body surface (including the gills).

These tracer studies are quite obviously not sufficient to draw definite conclusions. The sample is small, and desirable control experiments have not been performed. The experiments do suggest, however, that the "salt pump" operative in the adult is absent or operating less efficiently in the embryo. Further efforts in this direction are planned.
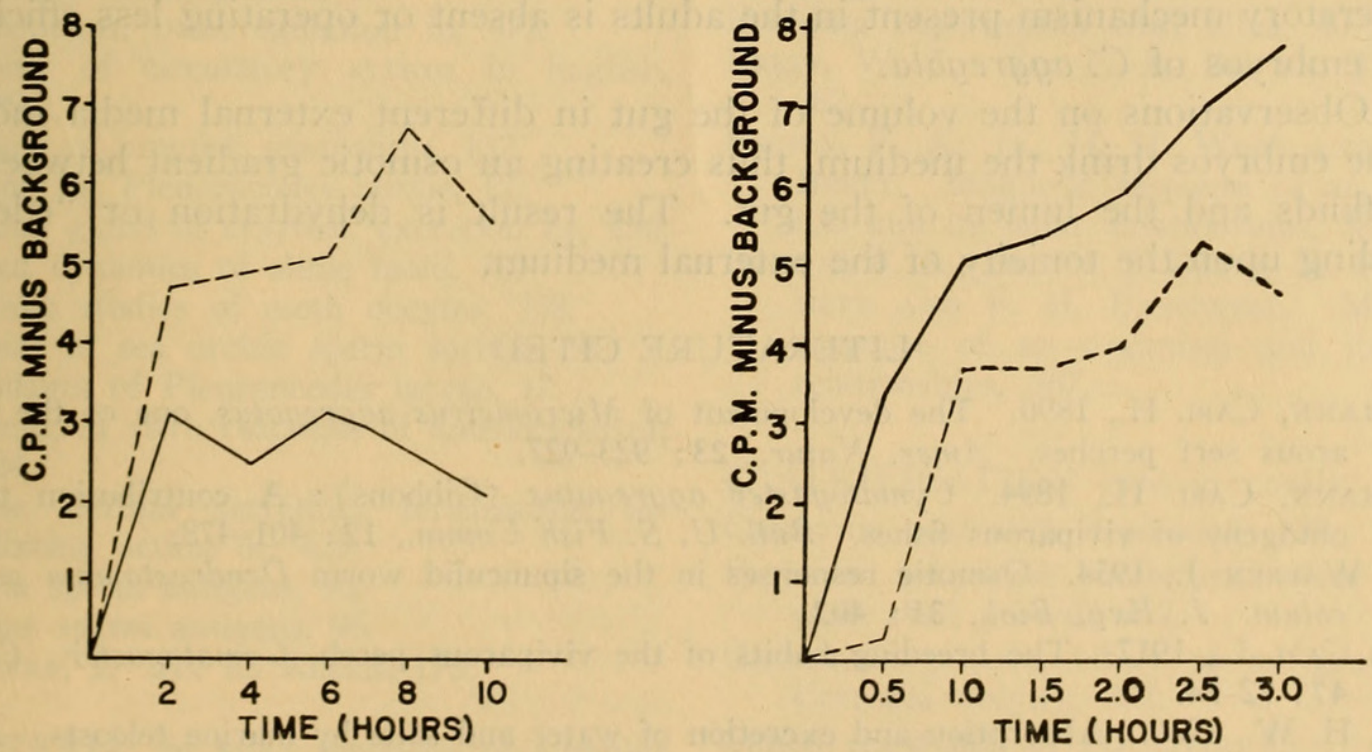

FIGURE 2. Radioactivity in front and back chambers of a divided box so arranged that the anterior half of a chloride ${ }^{36}$-injected fish is contained in the front chamber and the posterior half of the fish is contained in the back chamber. Dotted lines $=$ front chamber; solid lines $=$ back chamber. Left graph $=$ measurement for adult fish; right graph $=$ measurements for embryonic fish. 
Another clue concerning the lack of osmoregulatory ability in embryos was gained by observing the volume of the hindgut lumen in media of different osmotic concentrations. It was noted that embryos placed in any of the hypertonic solutions ( $>36 \%$ sea water) experience a swelling of the hindgut. The hindguts of animals placed in hypotonic solutions shrink. It is well known that marine teleosts maintain osmotic equilibrium by drinking sea water and excreting the excess salt, principally through the gills. It is hypothesized that these embryos also drink the external medium. If they should be placed in a hypertonic medium there would be created an osmotic gradient between body fluids and hindgut lumen resulting in body dehydration and swelling of the hindgut lumen. The opposite gradient would result if a hypotonic medium were drunk by the embryo. The question remains as to why this does not happen in the adult.

\section{Sum MARY}

1. The osmoregulatory abilities of adult and embryonic Cymatogaster aggregata were tested by determining serum freezing points and weight changes after exposure to dilutions of sea water ranging between 15 and 100 per cent.

2. Adults were able to regulate in external media ranging between 20 and 100 per cent sea water. The greatest deviations of weight and serum freezing point from the normal occur after one to two days in the experimental media. Regulation in all media is complete at or before nine days of exposure.

3. The ability of embryos to regulate is proportional to their stage of development. The youngest animals tested regulate only in media with values between 25 and 36 per cent sea water.

4. Similar though less extensive experiments were performed with adult Amphistichus argenteus and Micrometrus minimus. The osmoregulatory ability of these species is identical to that of adult $C$. aggregata.

5. Preliminary experiments using $\mathrm{Cl}^{36}$ as a tracer indicate that the branchial salt secretory mechanism present in the adults is absent or operating less efficiently in the embryos of $C$. aggregata.

6. Observations on the volume of the gut in different external media indicate that the embryos drink the medium, thus creating an osmotic gradient between the body fluids and the lumen of the gut. The result is dehydration or "edema," depending upon the tonicity of the external medium.

\section{LITERATURE CITED}

Eigenmann, Carl H., 1890. The development of Micrometrus aggregatus, one of the viviparous serf perches. Amer. Natur., 23: 923-927.

Eigenmann, Carl H., 1894. Cymatogaster aggregatus (Gibbons): A contribution to the ontogeny of viviparous fishes. Bull. U. S. Fish Comm., 12: 401-478.

Gross, Warren J., 1954. Osmotic responses in the sipunculid worm Dendrostomum zostericolum. J. Exp. Biol., 31: 402.

Hubbs, Carl L., 1917. The breeding habits of the viviparous perch, Cymatogaster. Copeia, 47: 72-74.

Sмmith, H. W., 1930. Absorption and excretion of water and salts by marine teleosts. Amer. J. Physiol., 93: 480-505.

TARP, Fred H., 1952. A revision of the family Embiotocidae (surf perches). Fish Bull. No. 88, California Div. Fish and Game, 99 p.

White, Philip R., 1954. The Cultivation of Plant and Animal Cells. The Ronald Press Co., New York, 239 p. 


\section{$2 \mathrm{BHL}$ Biodiversity Heritage Library}

Triplett, Edward L and Barrymore, Susanne D. 1960. "Some aspects of osmoregulation in embryonic and adult Cymatogaster aggregata and other embiotocid fishes." The Biological bulletin 118, 472-478.

https://doi.org/10.2307/1538825.

View This Item Online: https://www.biodiversitylibrary.org/item/110976

DOI: https://doi.org/10.2307/1538825

Permalink: https://www.biodiversitylibrary.org/partpdf/2150

\section{Holding Institution}

Smithsonian Libraries

\section{Sponsored by}

Biodiversity Heritage Library

\section{Copyright \& Reuse}

Copyright Status: In copyright. Digitized with the permission of the rights holder.

License: http://creativecommons.org/licenses/by-nc-sa/3.0/

Rights: https://biodiversitylibrary.org/permissions

This document was created from content at the Biodiversity Heritage Library, the world's largest open access digital library for biodiversity literature and archives. Visit BHL at https://www.biodiversitylibrary.org. 